\title{
Angiotropic large cell lymphoma (angioendotheliomatosis) presenting with protein-losing enteropathy
}

\author{
M.S. Al-Izzi, ${ }^{1}$ P.S. Sidhu, ${ }^{2}$ P.J. Garside ${ }^{2}$ and R. Menai-Williams ${ }^{1}$ \\ Departments of ${ }^{1}$ Histopathology and ${ }^{2}$ Medicine, Royal Berkshire Hospital, Craven Road, Reading, RG1 5AN, \\ $U K$.
}

\begin{abstract}
Summary: A 73 year old female presented with progressive hypoproteinaemic oedema which was resistant to treatment. The cause was not established until post-mortem, when it was found that she had angiotropic large cell lymphoma involving the vessels of the large intestine with mucosal ulceration. To our knowledge, this is the first report of angiotropic large cell lymphoma, which usually presents with neurological and skin involvement, presenting with protein-losing enteropathy.
\end{abstract}

\section{Introduction}

Angiotropic large cell lymphoma was first described by Pfleger \& Tappiner in 1959.' All the cases subsequently reported have presented with disease primarily of the central nervous system and skin. ${ }^{2}$ We report the first case of angiotropic large cell lymphoma presenting as protein-losing enteropathy.

\section{Case report}

A 73 year old Caucasian woman presented with a 6-week history of general malaise, exertional dyspnoea, orthopnoea and ankle swelling. She had been treated with frusemide $120 \mathrm{mg}$ and amiloride $15 \mathrm{mg} /$ day without symptomatic improvement. She had smoked and drunk heavily in the past, and suffered from recurrent bronchitis. In particular bowel function and intellect were normal.

On examination the jugular venous pressure was normal, but there was bilateral pitting ankle oedema and coarse lung crepitations. The blood pressure (BP) was $105 / 65 \mathrm{mmHg}$, pulse rate $54 / \mathrm{min}$ regular, and a smooth non-tender enlarged liver to $3 \mathrm{~cm}$. There was no ascites nor evidence of neurological impairment. Rectal examination was normal.

Initial investigations showed a normal peripheral blood count, differential and film. Erythrocyte sedimentation rate was $50 \mathrm{~mm} / \mathrm{h}$. Serum biochemistry showed sodium $127 \mathrm{mmol} / \mathrm{l}$, potassium $4.2 \mathrm{mmol} / \mathrm{l}$, urea $5.4 \mathrm{mmol} / 1$, glucose $5.4 \mathrm{mmol} / 1$. Chest radiograph and electrocardiogram were

Correspondence: M.S. Al-Izzi, M.S., M.R.C.Path.

Accepted: 15 October 1987 normal. Liver function tests showed only a mildly raised aspartate transaminase. Total serum protein was $48 \mathrm{~g} / 1$ and albumin $15 \mathrm{~g} / 1$. Kaolin cephalin clotting time was 52 seconds (control 41 seconds) and prothrombin time 14 seconds (control 12.5 seconds). Liver ultrasound was normal and the $24 \mathrm{~h}$ urinary protein was $0.2 \mathrm{~g} / \mathrm{l}$.

Diuretic therapy was reduced and subsequently stopped and a high protein diet instituted. However her clinical condition rapidly deteriorated with massive oedema, ascites and hypotension (BP $90 / 60 \mathrm{mmHg}$ ), hyponatraemia (sodium $114 \mathrm{mmol} / \mathrm{l}$ ), hyperkalaemia (potassium $6.9 \mathrm{mmol} / \mathrm{l}$ ) and a raised urea of $16.3 \mathrm{mmol} / \mathrm{l}$. Despite a pyrexia of $38^{\circ} \mathrm{C}$ the blood and urine cultures were negative. Ascitic fluid showed a protein content of less than $20 \mathrm{~g} / 1$ with no other abnormalities, and a short tetracosactrin test was within normal limits.

The patient responded to efforts aimed at reversing her hyperkalaemia, but the hyponatraemia became more profound despite infusions of human albumin and she died before further investigations of her hypoalbuminaemic state could be carried out.

At post-mortem areas of mucosal congestion were found in the stomach, small and large bowel. These became more confluent in the transverse and distal colon with central ulceration. The ulcers were of irregular shape and involved both the mucosa and the submucosa. Loose faecal material and a small quantity of altered blood were found in the lumen. The lungs showed severe congestion and oedema. In the adrenal glands and the pituitary gland there were multiple haemorrhagic nodular areas. The kidneys showed foci of subcapsular

(C) The Fellowship of Postgraduate Medicine, 1988 
congestion and haemorrhage. Similar haemorrhagic changes were also present in the bladder mucosa, endometrium and bone marrow. The brain, spleen and lymph nodes were all macroscopically normal, and no skin lesions were noted. Microscopically, the capillaries of all the organs examined were markedly dilated and filled with hyperchromatic, pleomorphic cells, with relatively small amounts of cytoplasm. Some were of giant form. Mitoses were noted (Figure 1). Cytologically, these cells were of the lymphoid series and the histological picture is that of angiotropic large cell lymphoma. This was confirmed by immunohistochemical stains with a panel of antibodies which demonstrated strongly positive staining for kappa and lambda light chains (Figure 2) and leukocyte common antigen and a less intensive positivity for pan B cell markers (4KB5 and L27). Some cells showed weakly positive staining for factor VIII, but the $T$ cell markers (UCHL1) and the epithelial markers (CAM 5.2 and KL1) were negative.

\section{Discussion}

The majority of previously reported cases of angiotropic large cell lymphoma have presented with either neurological symptoms and signs or skin manifestations, even though post-mortem tissue revealed widespread organ involvement. ${ }^{2-5}$ Our patient had profound hypoalbuminaemia secondary to extensive gut ulceration and had no neurological or skin manifestations.

The outcome has been universally fatal, but recent success has been reported using combination chemotherapy. ${ }^{5-6} \mathrm{We}$ were unable to make an antemortem diagnosis on our patient due to the atypical presentation, and were unable to treat her with any chemotherapy.

Angiotropic large cell lymphoma seems therefore to be capable of manifesting itself clinically not just neurologically or dermatologically, but in other forms as well.

\section{References}

1. Pfleger, V.L. \& Tappeiner, J. Zur Kenntnis dersystemisierten endotheliomastose der cutanenblutgefasse (reticuloendotheliosis?). DerHautarzt 1959, 10: $359-363$.

2. Petito, C.K., Gottlieb, G.J., Doughterty, J.H. et al. Neoplastic angioendotheliosis. Ultrastructural study and review of literature. Ann Neurol 1978, 3: 393-399.

3. Feivez, M., Feivez, C. \& Hustin, J. Proliferating systematized angioendotheliomatosis. Arch Dermatol 1971, 104: 320-324.

4. Carrol, T.J., Schelper, R.L., Goeken, J.A. \& Kemp,

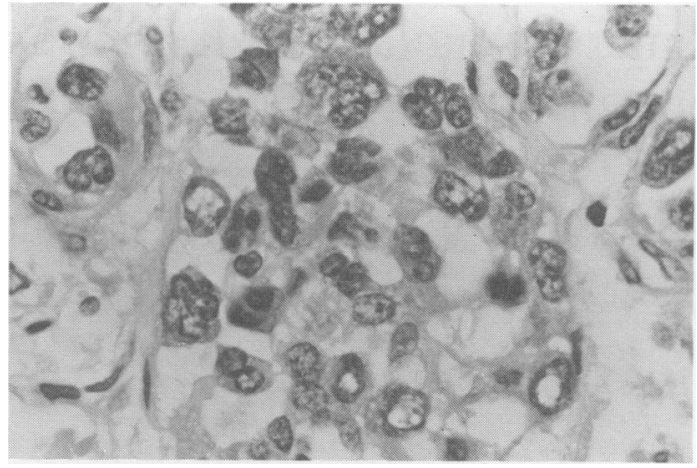

Figure 1 A dilated capillary with a large number of pleomorphic cells, some with lobulated nuclei and mitotic figures. Haematoxylin and eosin stain $\times 800$.

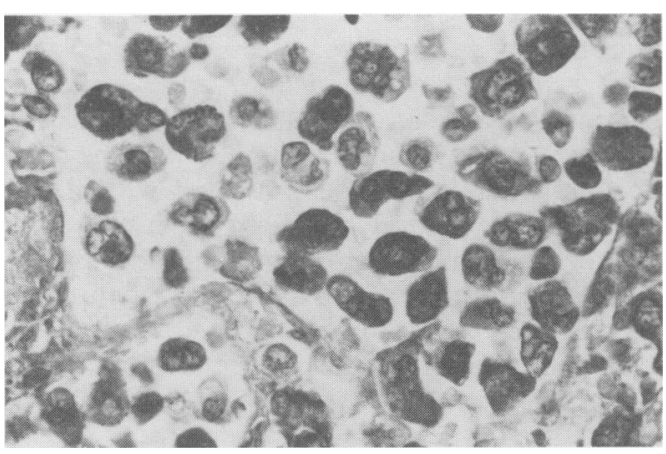

Figure 2 A large number of intravascular malignant cells show positive granular cytoplasmic staining with antiserum specific for lambda light chain. PAP $\times 800$.

\section{Acknowledgements}

The authors thank Dr J. Theaker and the Department of Histopathology at John Radcliffe Hospital, Oxford, for their help in the immunohistochemical staining and Mrs M. Roach for the technical help.

J.D. Neoplastic angioendotheliomatosis: immunological and morphological evidence for intravascular malignant lymphomatosis. Am J Clin Pathol 1986, 85: 169-175.

5. Sheibani, K., Battifora, H., Winberg, C. et al. Further evidence that malignant angioendotheliomatosis is an angiotropic large cell lymphoma. N Engl J Med 1986, 413: $943-948$.

6. Shiozaki, H., Hoshino, S., Oshimi, K. et al. A case report of neoplastic angioendotheliosis which responded to combination chemotherapy (CHOP). J Jpn Soc Intern Med 1983, 73: 374-378. 